\title{
Validation of the Scandinavian Stroke Scale in a Multicultural Population in Brazil
}

\author{
Gustavo José Luvizutto ${ }^{a}$ Tamiris Aparecida Monteiro ${ }^{a}$ \\ Gabriel Braga $^{a}$ Octavio Marques Pontes-Neto ${ }^{b}$ \\ Luiz Antônio de Lima Resende ${ }^{a}$ Rodrigo Bazan ${ }^{a}$ \\ a Neurology Service of Botucatu Medical School, University Estadual Paulista \\ Júlio de Mesquita Filho, and ${ }^{b}$ Neurology Service of Ribeirão Preto Medical School, \\ University of São Paulo, São Paulo, Brazil
}

\section{Key Words}

Stroke $\cdot$ Stroke unit $\cdot$ Scandinavian Stroke Scale $\cdot$ Stroke trials $\cdot$ Brazil

\begin{abstract}
Background: The objective of this study was to evaluate the consistency, coherence, and interobserver reliability of the Portuguese version of the Scandinavian Stroke Scale (SSS) in a multicultural population of stroke. Methods: The SSS was translated, culturally adapted, and applied by two independent investigators. This was a randomized transverse study involving two groups: group 1 included 20 patients in the acute phase and group 2 included 20 patients in the subacute phase after stroke was confirmed by computed tomography with a pre-stroke modified Rankin Scale score of 0 . Each patient also underwent National Institutes of Health Stroke Scale (NIHSS) evaluation at hospital entry and at the time of the SSS evaluation for correlation with our current standard hospital practice. Consistency and coherence were analyzed by Cronbach's $\alpha$ and interobserver reliability by к. Results: Forty patients were evaluated with 0.88 consistency and coherence in both stroke phases. Mean interobserver $\kappa$ was 0.76 , with reliability considered excellent and good for most scale items, and moderate for only the facial palsy item. Conclusion: The SSS is adequate and validated to study post-stroke patients in a multicultural Brazilian population and in the Portuguese language.

Copyright $\odot 2012$ S. Karger AG, Basel
\end{abstract}




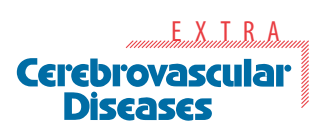

\section{Introduction}

Stroke is the main cause of mortality and incapacity in the USA, Latin America, and in the Brazilian population, with around 200,000 cases annually [1-3]. Instruments to evaluate individuals after stroke have become increasingly important today in order to determine incapacity level or to help evaluate behaviors and observe the efficacy of proposed treatments [4].

The Scandinavian Stroke Scale (SSS) is designed to give a score based on level of consciousness, eye movement, and severity of paralysis $[5,6]$. Many studies have used the SSS to measure disability or evaluate prognosis of stroke patients and to compare treatment outcomes [7-10], and its application has become routine in hospitals treating stroke patients since it can be used as a predictor for morbidity, mortality, and incapacity level in this population [11-13].

Although two thirds of stroke cases occur in developing countries, most evaluation instruments have been developed in the English language. A review of the literature did not reveal a version in the Portuguese language or any study on its reliability in Brazil. The objective of our study was to evaluate the consistency and coherence of the instrument and the interobserver reliability of the Portuguese version of the SSS in post-stroke individuals.

\section{Materials and Methods}

After approval by Botucatu School of Medicine (University Hospital Research Ethics Committee), 40 patients were evaluated between January and July 2012 with a diagnosis of stroke confirmed by head computed tomography. This was a randomized transverse study involving two groups: group 1 included 20 patients in the acute phase (up to $48 \mathrm{~h}$ after the ictal phase) and group 2 included 20 patients in the subacute phase (from $48 \mathrm{~h}$ to 1 month after the ictal phase). Patients with acute- or subacute-phase unique unilateral stroke, aged $>18$ years, and with a score of 0 on the modified Rankin Scale (mRS) were included, while patients with other associated central or peripheral neurological diseases, prior stroke or a score of $\geq 1$ on the mRS were excluded. The SSS was initially translated into Portuguese by a Brazilian specialized professional fluent in English. After initial translation (version 1), the scale was sent to a native English translator, resulting in a reverse translation (version 2). Versions 1 and 2 were evaluated by the authors by comparing them with the original text to correct discrepancies and draw up a compatible version without inconsistencies (table 1). This instrument was applied by two physiotherapists from the neurorehabilitation team with each assessor receiving a copy of the scoring criteria and the general rules for the scale a week prior to application; the scale was applied in an independent manner, without prior knowledge of the neurological alterations or scoring of the other assessor. The SSS contains nine items which generate a minimum score of 2 (worst neurological compromise) and a maximum score of 56 (without neurological compromise), with item $1=$ consciousness (score $2-6$ ); 2 = eye movement (score $0-4) ; 3=$ arm motor power (score $0-6$ ); $4=$ hand motor power (score $0-6$ ); $5=$ leg motor power (score $0-6$ ); $6=$ orientation (score $0-6$ ); 7 = speech (score $0-10) ; 8=$ facial palsy (score $0-2$ ), and $9=$ gait (score $0-12$ ). In addition to the SSS, it is routine in the hospital neurology service to apply the National Institutes of Health Stroke Scale (NIHSS) upon patient arrival; the NIHSS was reapplied at the same time as the SSS by both assessors.

Statistical analysis consisted of a descriptive analysis (frequency and percentage) for qualitative variables (gender, age, lesion topography, and stroke phase) and mean and standard deviation for quantitative variables (weight, height, and body mass index). Consistency 
Table 1. Scandinavian Stroke Scale in Portuguese

Pontuação

Consciência

Plenamente consciente

Sonolento, pode ser acordado para consciência plena

Reage ao comando verbal, mas não é totalmente consciente 2

Movimento dos olhos

Sem paralisia do olhar

Presença de paralisia do olhar 2

Desvio do olhar conjugado 0

Braço, força muscular*

Levanta o braço com força normal

Levanta o braço com força reduzida

Levanta o braço com flexão do cotovelo 4

Pode se mover, mas não contra a gravidade 2

Paralisia completa (sem movimentação) 0

Mão, força muscular*

Força muscular normal 6

Redução da força em amplitude total de movimento 4

Algum movimento, os dedos não chegam na palma da mão 2

Paralisia completa (sem movimentação) 0

Perna, força muscular*

Força muscular normal

Levanta a perna reta com redução da força muscular

Levanta a perna com flexão do joelho 4

Pode se mover, mas não contra a gravidade 2

Paralisia completa (sem movimentação) 0

Orientação

Orientado em tempo, espaço e pessoa $\quad 6$

Dois desses 4

Um desses 2

Completamente desorientado 0

Fala

Sem afasia 10

Vocubulário limitado ou fala incoerente 6

Responde com sim/não, mas não fala sequências longas 3

Responde somente com sim/não 0

Paralisia facial

Nenhuma/duvidoso 2

Presente 0

Movimentação

Pode caminhar 5 metros sem auxílio $\quad 12$

Pode caminhar com meio auxiliar (andador, muleta, bengala) 9

Pode caminhar somente com auxílio de outra pessoa 6

Senta sem apoio 3

Acamado/Cadeira de rodas 0

Pontuação máxima

* Motor power is assessed only on the affected side. 
Table 2. Sample population

\begin{tabular}{llll}
\hline & \multicolumn{2}{l}{ Phase } & \\
\cline { 2 - 3 } & G1 & G2 & p value \\
\hline Age, years & $63.4 \pm 14.4$ & $70.6 \pm 14.7$ & 0.130 \\
Weight, $\mathrm{kg}$ & $68.2 \pm 13.7$ & $62.4 \pm 10.0$ & 0.135 \\
Height, $\mathrm{m}$ & $1.66 \pm 0.09$ & $1.61 \pm 0.06$ & 0.053 \\
BMI & $24.5 \pm 3.7$ & $24.0 \pm 3.4$ & 0.673 \\
Gender, male:female & $11: 9$ & $8: 12$ & - \\
Hemisphere, ND:D & $7: 13$ & $11: 9$ & - \\
Prior mRS & 0 & 0 & - \\
NIHSS (a) & $11.8 \pm 6.7$ & $11.7 \pm 7.4$ & 0.982 \\
NIHSS (b) & $10.1 \pm 7.8$ & $12.1 \pm 8.2$ & 0.441 \\
\hline
\end{tabular}

Data are means \pm SD unless otherwise indicated.

$\mathrm{G} 1$ = Acute phase; $\mathrm{G} 2$ = subacute phase; $\mathrm{BMI}=$ body mass index; $\mathrm{ND}=$ non-dominant; $\mathrm{D}$ = dominant; (a) = on admission at the hospital; (b) = during application of the SSS.

Table 3. Interobserver agreement for the SSS items

\begin{tabular}{lll}
\hline Scale item & $\kappa$ & $95 \% \mathrm{CI}$ \\
\hline Consciousness & 0.84 & $0.70-0.99$ \\
Eye movement & 0.69 & $0.47-0.92$ \\
Arm, motor power & 0.72 & $0.56-0.89$ \\
Hand, motor power & 0.67 & $0.49-0.84$ \\
Leg, motor power & 0.76 & $0.60-0.92$ \\
Orientation & 0.86 & $0.73-0.99$ \\
Speech & 0.69 & $0.48-0.84$ \\
Facial palsy & 0.59 & $0.35-0.83$ \\
Gait & 1.0 & $1.0-1.0$ \\
\hline
\end{tabular}

and coherence of the instrument were evaluated calculating Cronbach's $\alpha$ coefficient, and interobserver consistency was obtained by the $\kappa$ coefficient, considering $<0.20$ as a poor, $0.20-0.39$ as a fair, $0.40-0.59$ as a moderate, $0.60-0.79$ as a good, and $>0.8$ as an excellent association. Comparisons between the quantitative variables 'stroke phase' and 'lesion topography' were made by using the Student's t test for independent samples and Spearman correlation to ascertain possible dependencies between the NIHSS and the SSS. All tests used a $5 \%$ significance level or the corresponding $p$ value.

\section{Results}

Over a period of 6 months, 40 patients were evaluated; there was no statistical difference in demographic profile between groups 1 and 2, noting studied sample homogeneity (table 2).

Instrument consistency and coherence were established as $\alpha=0.886$ in group 1 and $\alpha=$ 0.889 in group 2. Interobserver concordance was considered excellent for consciousness level, orientation, and global movement; good for eye movement, speech, and arm, hand, and leg muscular force, and moderate for facial palsy. The SSS presented negative correlation with 
Table 4. Lesion topography and scale scores in the acute phase

\begin{tabular}{llcl}
\hline & \multicolumn{2}{l}{ Hemisphere } & \\
\cline { 2 - 3 } & dominant & non-dominant & p value \\
\hline NIHSS (a) & $14.6 \pm 7.0$ & $9.4 \pm 6.2$ & 0.019 \\
NIHSS (b) & $15.5 \pm 7.8$ & $7.5 \pm 6.5$ & 0.001 \\
SSS & $18.8 \pm 15.2$ & $33.9 \pm 16.2$ & 0.004 \\
\hline
\end{tabular}

Data are means \pm SD. $(a)=$ On admission at the hospital; $(b)=$ during application of the SSS.

the NIHSS $(\mathrm{p}<0.001)$ in the acute phase $(\mathrm{r}=-0.96)$ and subacute phase $(\mathrm{r}=-0.88)$, with the interobserver concordance rate not differing significantly between scales (table 3 ).

A lower total SSS score was seen in individuals with stroke in the dominant hemisphere compared to the non-dominant hemisphere, demonstrating a strong association with the language item in establishing scale total score (table 4).

\section{Discussion}

This study demonstrated good interobserver concordance indices for the SSS, which validates the scale in a Brazilian multicultural population and in the Portuguese language. The SSS items were translated and the gait item adapted to Brazilian culture to differentiate between individuals walking with aids (crutches, canes or walkers) or with the help of another person; the SSS was easily applied by professionals.

Most items on the scale presented good results, displaying high concordance rates between assessors; however, facial palsy classification was variable, which was also reported for the NIHSS [4]. This aspect could be due to subjectivity of assessors in evaluating this item and due to the fact that it is only divided into two items on the scale.

Consciousness and orientation presented high concordance rates, possibly because they are objective items, and the scale has a high correlation in the acute stroke phase, where such aspects are more visible and detectable in neurological evaluation. The items related to palsy severity obtained a good concordance level, which shows that the instrument can predict motor recuperation in affected individuals.

The SSS gives preference to structuring its questions to evaluate the dominant hemisphere, which is also demonstrated in the NIHSS, mainly due to the fact that the speech item contributes $5.8 \%$ of the total scale score, permitting possible underestimation of lesions in the right hemisphere. The scoring of the SSS differs from the NIHSS, and the relationships in scoring between the scales need to be reviewed carefully. A conversion into established standards is necessary as shown in previous studies [14]. In this work, we observed inversely proportional values with the NIHSS, giving higher association in the acute stroke phase. This finding is important, as the NIHSS is used as a fast rating scale with an estimated application time of $<5-10 \mathrm{~min}$, allowing it to be used in the acute phase to guide treatments and define prognosis.

In conclusion, the SSS is adequate and valid for studying patients after stroke in a Brazilian multicultural population and in the Portuguese language. 


\section{References}

-1 Sen S, Rabinstein AA, Elkind MS, Powers WJ: Recent developments regarding human immunodeficiency virus infection and stroke. Cerebrovasc Dis 2012;33:209-218.

-2 Saposnik G, Del Brutto OH, Iberoamerican Society of Cerebrovascular Diseases: Stroke in South America: a systematic review of incidence, prevalence, and stroke subtypes. Stroke 2003;34:21032108.

-3 Mansur AP, de Souza MFM, Favarato D, Avakian SD, Machado CLA, Aldrigui JM, Franchini RJA: Stroke and ischemic heart disease mortality trends in Brazil from 1979 to 1996. Neuroepidemiology 2003;22:179-183.

-4 Cincura C, Pontes-Neto OM, Neville IS, Mendes HF, Menezes DF, Mariano DC, Pereira IF, Teixeira LA, Jesus PA, de Queiroz DC, Pereira DF, Pinto E, Leite JP, Lopes AA, Oliveira-Filho J: Stroke Scale, modified Rankin Scale and Barthel Index in Brazil: the role of cultural adaptation and structured interviewing. Cerebrovasc Dis 2009;27:119-122.

-5 Oxbury JM, Greenhall RC, Grainger KM: Predicting the outcome of stroke: acute stage after cerebral infarction. Br Med J 1975;19:125-127.

-6 Scandinavian Stroke Study Group: Multicenter trial of hemodilution in ischemic stroke - background and study protocol. Stroke 1985;16:885-890.

7 De Haan R, Horn J, Limburg M, Van Der Meulen J, Bossuyt P: A comparison of five stroke scales with measures of disability, handicap, and quality of life. Stroke 1993;24:1178-1181.

-8 Cabral NL, Moro C, Silva GR, Scola RH, Werneck LC: Study comparing the stroke unit outcome and conventional ward treatment: a randomized study in Joinville, Brazil. Arq Neuropsiquiatr 2003;61: $188-193$.

-9 Rödén-Jüllig A, Britton M, Gustafsson C, Fugl-Meyer A: Validation of four scales for the acute stage of stroke. J Intern Med 1994;236:125-136.

10 Barber M, Fail M, Shields M, Stott DJ, Langhorne P: Validity and reliability of estimating the Scandinavian stroke scale score from medical records. Cerebrovasc Dis 2004;17:224-227.

-11 Christensen H, Boysen G, Truelsen T: The Scandinavian stroke scale predicts outcome in patients with mild ischemic stroke. Cerebrovasc Dis 2005;20:46-48.

-12 Andersen KK, Andersen ZJ, Olsen TS: Predictors of early and late case-fatality in a nationwide Danish study of 26,818 patients with first-ever ischemic stroke. Stroke 2011;42:2806-2812.

-13 Rønning OM, Stavem K: Predictors of mortality following acute stroke: a cohort study with 12 years of follow-up. J Stroke Cerebrovasc Dis 2012;21:369-372.

- 14 Ali K, Cheek E, Sills S, Crome P, Roffe C: Development of a conversion factor to facilitate comparison of National Institute of Health Stroke Scale scores with Scandinavian Stroke Scale scores. Cerebrovasc Dis 2007;24:509-515. 